University of Nebraska - Lincoln

DigitalCommons@University of Nebraska - Lincoln

Mammalogy Papers: University of Nebraska

State Museum

Museum, University of Nebraska State

12-15-1983

Brachyphylla cavernarum

Pierre Swanepoel

Kaffrarian Museum, South Africa

Hugh H. Genoways

University of Nebraska - Lincoln, h.h.genoways@gmail.com

Follow this and additional works at: https://digitalcommons.unl.edu/museummammalogy

Part of the Zoology Commons

Swanepoel, Pierre and Genoways, Hugh H., "Brachyphylla cavernarum" (1983). Mammalogy Papers: University of Nebraska State Museum. 93.

https://digitalcommons.unl.edu/museummammalogy/93

This Article is brought to you for free and open access by the Museum, University of Nebraska State at DigitalCommons@University of Nebraska - Lincoln. It has been accepted for inclusion in Mammalogy Papers: University of Nebraska State Museum by an authorized administrator of DigitalCommons@University of Nebraska Lincoln. 


\title{
Brachyphylla cavernarum.
}

By Pierre Swanepoel and Hugh H. Genoways

\author{
Published 15 December 1983 by The American Society of Mammalogists
}

\section{Brachyphylla Gray, 1834}

\section{Fruit-eating Bats}

Brachyphylla Gray, 1834:122. Type species Brachyphylla cavernarum Gray.

CONTEXT AND CONTENT. Order Chiroptera, Family Phyllostomidae, Subfamily Brachyphyllinae. The genus Brachy. phylla consists of two species. The following will aid in identification (measurements in $\mathrm{mm}$ ):

Mandibular length 18.9 or longer; length of maxillary toothrow 10.0 or longer; occurs east of Mona Passage (Puerto Rico and Lesser Antilles) Brachyphylla cavernarum

Mandibular length 18.2 or shorter; length of maxillary toothrow 9.9 or shorter; occurs west of Mona Passage (Greater Antilles except Puerto Rico)

Brachyphylla nana

DIAGNOSIS. Brachyphylla resembles the other brachyphyllines externally in all respects except for having a more stocky build and shorter snout; lower lip with median groove ridged by papillae; nodular ridges on chiropatagium; calcar absent or very small; five lumbar vertebrae, fifth lacking spine; skull relatively long, narrow; upper incisors markedly different in size and shape, inner one large, higher than long, recurved, outer one rounded, minute, flat-crowned; anterior upper premolar minute; posterior upper premolar high and short; crowns of upper and lower molars heavily wrinkled; first lower molar with distinct posteriointernal cusp, differing markedly from last premolar; interpterygoid space not extending forward as a palatal emargination; posterior palatal emargination narrow, V-shaped; nasal region without emargination; ears small, separate; nose-leaf rudimentary; pectoral process of the humerus low and not developed into a flange; tail very short if present and wholly enclosed by interfemoral membrane. Dentition is i $2 / 2$, c $1 / 1, \mathrm{p} 2 / 2, \mathrm{~m} 3 / 3$, total 32 . Karyotype is $2 \mathrm{n}=32 ; \mathrm{FN}=60$.

\section{Brachyphylla cavernarum Gray, 1834 Lesser Antillean Fruit-eating Bat}

Brachyphylla cavernarum Gray, 1834:123. Type locality St. Vincent, Lesser Antilles.

Brachyphylla minor Miller, 1913:32. Type locality Cole's Cave, St. Thomas Parish, Barbados.

CONTEXT AND CONTENT. Context is given in the generic account above. Three subspecies currently are recognized (Swanepoel and Genoways, 1978) as follows:

B. c. cavernarum Gray (1834:123), see above,

B. c. intermedia Swanepoel and Genoways (1978:38). Type locality $1 \mathrm{mi}$ W Corozal, Puerto Rico.

B. c. minor Miller (1913:32), see above.

DIAGNOSIS. Size large for the genus in external and cranial measurements. See also aid to identification above. The cranium and mandible of B. cavernarum are illustrated in Fig. 1 .

GENERAL CHARACTERISTICS. Color in the genus Brachyphylla does not exhibit a great deal of variation. Typically the hair is white to yellowish white at the base with the tips darker in some areas on the dorsum. These darker areas, which vary in size, occur as a distinct patch on top of the head and neck and a $\mathrm{V}$-shaped mantle starting approximately at the shoulders and meeting posteriorly in the middle of the dorsum. The flanks are usually lighter colored. The darker areas may be blackish gray, blackish brown, grayish brown, or dark brown in color (see Fig. 2).

In a morphometric analysis of chiropteran wings, Smith and Starrett (1979) found that members of the Brachyphyllinae have the shortest wings, relatively, among the phyllostomids. They re- semble phyllostomines in possessing relatively long forearms and have the shortest relative length of digit III as compared to the other members of the family. Smith and Starrett (1979) gave a number of statistical values for the wings of Brachyphylla.

Secondary sexual dimorphism is present. Males exceeded females significantly in size in all 16 measurements tested, except length of ear from one or more localities, whereas females proved to be significantly larger than males only in length of hindfoot in the sample from eastern Puerto Rico, and in breadth across upper molars in specimens from St. Lucia (Swanepoel and Genoways, 1978).

Brachyphylla cavernarum minor is distinguished by its small size, and occurs on Barbados. It is phenetically the most distinct of
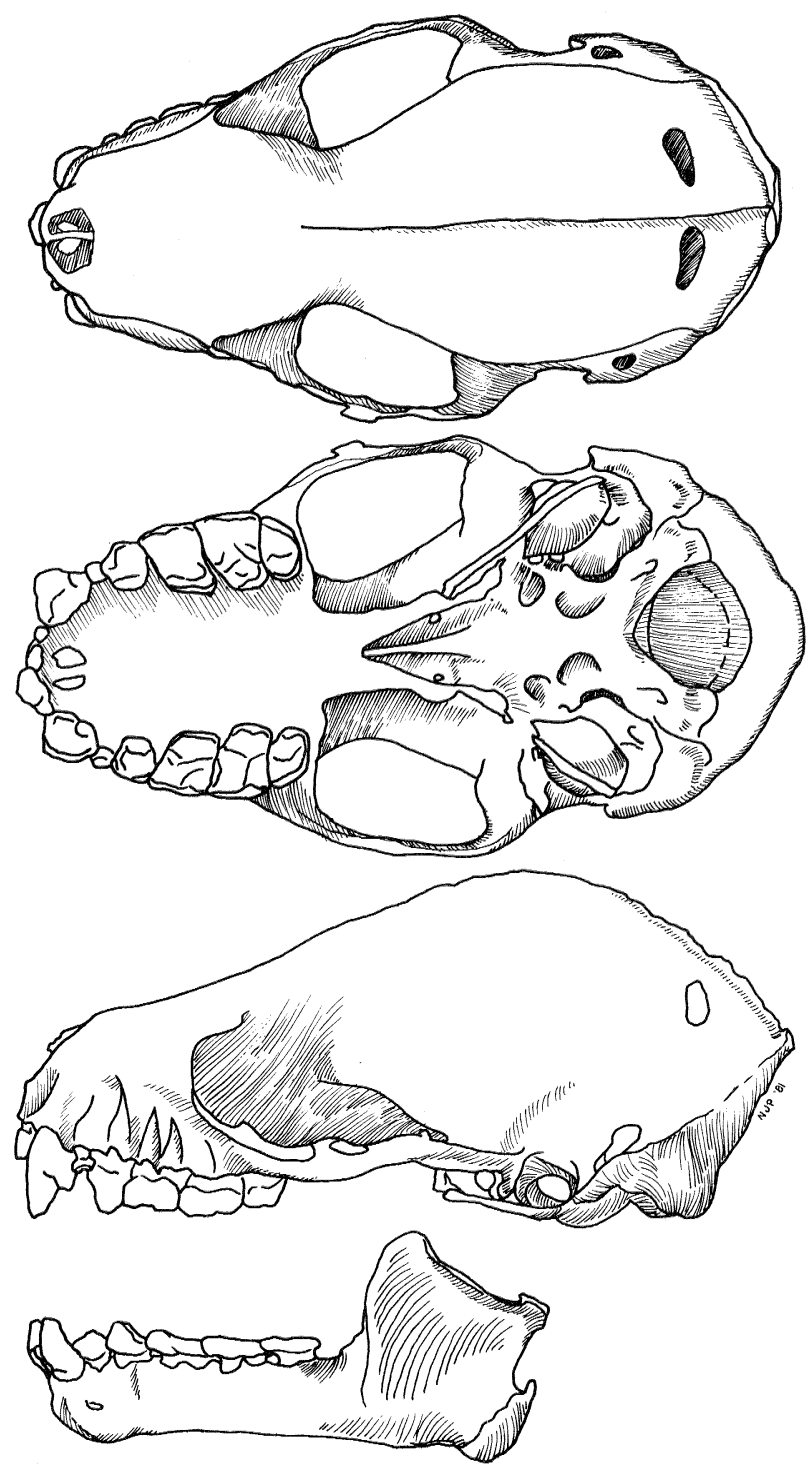

Figure 1. Dorsal, ventral, and lateral views of cranium and lateral view of lower jaw of Brachyphylla cavernarum intermedia ( $\delta, \mathrm{CM}$ 44708) from Puerto Rico. Greatest length of skull is $32.5 \mathrm{~mm}$. Drawn by Nancy J. Perkins. 

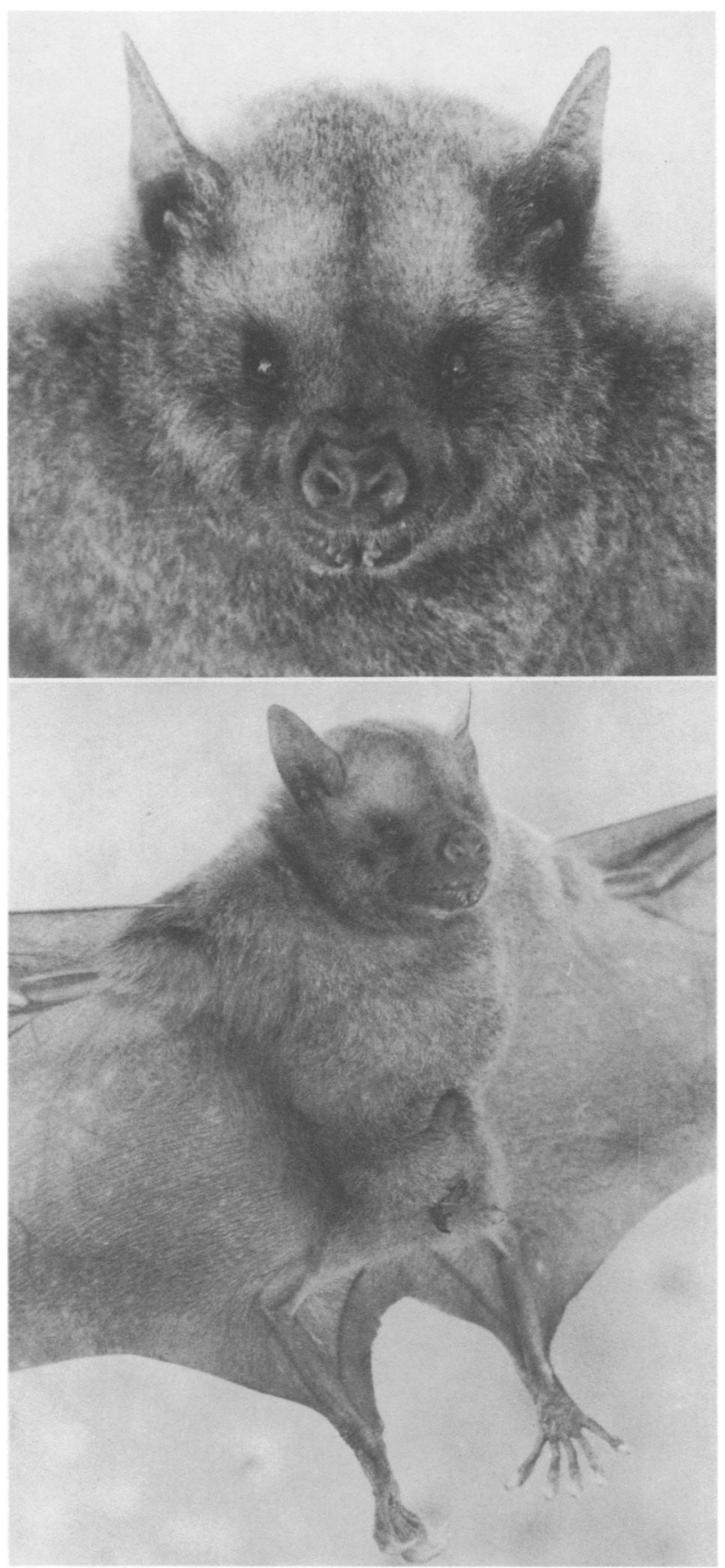

Figure 2. Male Brachyphylla cavernarum cavernarum photographed on Guadeloupe Island by Robert J. Baker.

all the subspecies. The nominate subspecies, Brachyphylla cavernarum cavernarum, includes the largest individuals, and occurs on St. Croix in the Virgin Islands and Anguilla southward through the Lesser Antilles to St. Vincent. The third subspecies, Brachyphylla cavernarum intermedia, is intermediate in size and occurs on Puerto Rico and most of the Virgin Islands (St. John, Norman, and St. Thomas, excluding St. Croix). This subspecies is not distinguished by any one single character, but its overall size as measured in multivariate analyses indicates that $80 \%$ to $90 \%$ of the individuals in this population are distinguishable from Lesser Antillean populations.

The range and sample size of external and cranial measurements (in $\mathrm{mm}$ ) of males and females for B. c. minor are as follows: total length, 90 to 92 (3), 86 to 94 (8); length of hindfoot, 20 to 22 (3), 20 to 23 (8); length of ear, 22 to 23 (3), 22 to 23 (8); length of forearm, 59.2 to 63.1 (6), 59.3 to 62.4 (12); greatest length of skull, 30.0 to 31.2 (7), 29.6 to 30.9 (11); condylobasal

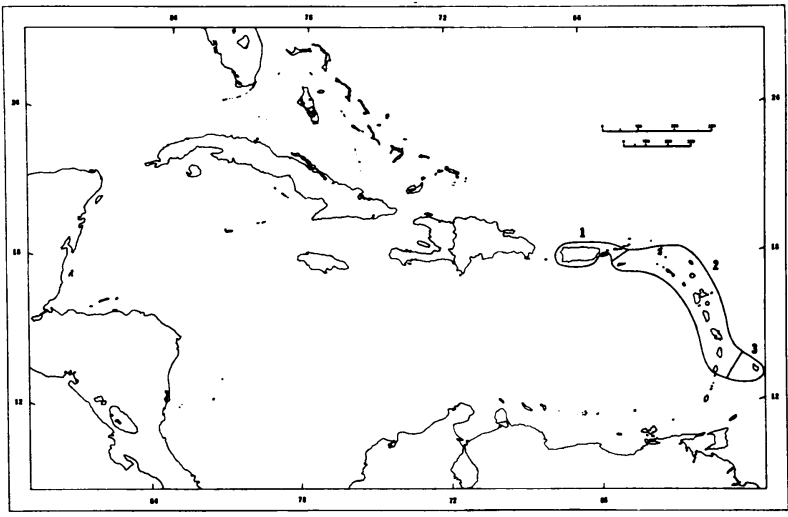

Figure 3. Geographic distribution of Brachyphylla cavernarum: $1, B$. c. intermedia; $2, B$. c. cavernarum; and $3, B$. c. minor. The upper scale is in kilometers and the lower in miles.

length, 26.3 to 27.7 (7), 26.3 to 27.6 (12); palatal length, 10.7 to 12.0 (7), 10.7 to $12.3(12)$; depth of braincase, 13.0 to 13.2 (6), 12.2 to 13.3 (12); zygomatic breadth, 16.2 to 16.7 (8), 16.0 to 17.2 (10); breadth of braincase, 12.2 to $12.7(8), 11.9$ to 12.7 (12); mastoid breadth, 13.7 to 14.8 (7), 13.7 to 14.6 (12); postorbital breadth, 6.1 to $6.6(8), 5.8$ to 6.5 (12); length of maxillary toothrow, 10.3 to $10.9(8), 10.0$ to 10.8 (12); rostral width at canines, 6.6 to $7.2(8), 6.3$ to 7.0 (12); breadth across upper molars, 10.9 to $11.5(8), 10.8$ to 11.9 (11); mandibular length, 18.9 to 20.0 (7), 19.1 to 20.3 (11).

Values for Brachyphylla c. cavernarum are as follows: total length, 80 to 98 (37), 86 to 103 (30); length of hindfoot, 18 to 23 (37), 17 to 23 (19); length of ear, 18 to 24 (23), 18 to 23 (14); length of forearm, 59.6 to 68.9 (94), 60.4 to 71.1 (68); greatest length of skull, 30.9 to 33.0 (96), 30.4 to 33.3 (85); condylobasal length, 27.1 to 29.8 (93), 26.8 to 29.4 (81); palatal length, 10.6 to $13.1(97)$, 11.1 to 13.1 (81); depth of braincase, 12.3 to $14.4(92), 12.4$ to 14.1 (82); zygomatic breadth, 16.0 to 18.2 (91), 16.3 to 18.3 (79); breadth of braincase, 12.2 to 13.4 (98), 12.1 to 13.4 (85); mastoid breadth, 14.1 to 15.6 (93), 14.0 to 15.9 (82); postorbital breadth, 5.9 to $6.9(99), 6.0$ to 6.7 (86); length of maxillary toothrow, 10.5 to 11.6 (97), 10.5 to 11.4 (83); rostral width at canines, 6.7 to 8.1 (97), 6.7 to 7.7 (85); breadth across upper molars, 11.0 to 12.4 (96), 10.9 to 12.4 (85); mandibular length, 19.7 to 21.5 (90), 19.4 to 21.3 (79).

DISTRIBUTION. Brachyphylla cavernarum occurs on Puerto Rico, the Virgin Islands, and down the Lesser Antillean chain as far as St. Vincent and Barbados (Fig. 3).

FOSSIL RECORD. Fossils of Brachyphylla cavernarum are known on Puerto Rico from Cueva Cathedral (Anthony, 1918), at a late Pleistocene level according to Smith (1976); from Cueva Monte Grande at an unspecified time level (Reynolds et al., 1953); from Cueva de Clara, Cueva del Perro, and Cueva de Silva in subRecent times (Choate and Birney, 1968); and from Antigua in subRecent times (Wing et al., 1968).

FORM AND FUNCTION. Baker and Genoways (1978) ascribed the success of $B$. cavernarum, which occurs on at least 13 of the 19 major islands in its range, to its large, robust size and varied diet.

Wing loading was found to be in the range of $16 \mathrm{~g} / \mathrm{cm}^{2}$ (Nellis and Ehle, 1977). Nellis (1971) reported B. cavernarum carrying sapodilla fruits (Manilkara zapota). These fruits weighed 30 to 34 $\mathrm{g}$, whereas the bats weighed 34.4 to $49.2 \mathrm{~g}$. However, in captivity Nellis and Ehle (1977) found that these bats were unable to carry fruit half their body weight. These authors reported that the intestinal transit time was $15 \mathrm{~min}$, which agrees with the findings of Klite (1965) for other bats.

In a study of thermoregulation in B. cavernarum from St. Croix, McManus and Nellis (1972; see also McManus, 1977) found this species to be a good thermoregulator, showing greater resistance to cold stress than Artibeus jamaicensis and Molossus molossus. The 20 test animals, which had a mean weight of $40.1 \mathrm{~g}$ (range 31.1 to 45.1 ), had rectal temperatures of $39.8 \pm \mathrm{SD} 0.40^{\circ} \mathrm{C}$. Exposure to ambient temperature of $10.6 \pm \mathrm{SD} 3.13^{\circ} \mathrm{C}$ (range 4.5 to 14.3 ) caused a continuous decrease in body temperature throughout the period of exposure. After $24 \mathrm{~h}$, body temperature was still 
above $25^{\circ} \mathrm{C}$. None of the test animals died during exposure. Nellis and Ehle (1977) concluded that body temperature in young animals seemed to be lowered during sleep in contrast with that of adults.

Benedict (1957) provided a detailed description and photographs of the hair structure of $B$. cavernarum. The overhair was found to average $9 \mathrm{~mm}$ in length and to have a maximum diameter of 30.6 microns and a diameter of 25.5 microns at the midpoint of the hair. The maximum diameter of hair is in the distal portion. Melanin granules were generally dispersed in the distal two-thirds of the filament, with most in the distal third. The scale form was of the medium and short, erose coronal type.

The results of hematological determinations by Valdivieso and Tamsitt (1971) showed polychromatophilia in B. cavernarum in $65 \%$ of the samples, normoblasts in $33 \%$, and cabot rings, usually seen in stained erythrocytes of severe anemias, in $22 \%$. Hemograms (percentages of leucocytes of each type) for two males, three females, and four gravid females from St. Croix, respectively, were given by Valdivieso and Tamsitt (1971) as follows (mean $\pm 1 \mathrm{SE}$, range): neutrophils, 70.5 (70 to 71$), 60.0(55$ to 65$), 56.8 \pm 2.8$ (5l to 64); lymphocytes, 24.0 (24), 34.7 (32 to 37 ), $38.5 \pm 2.4$ (32 to 42); eosinophils, 2.0 ( 1 to 3 ), 2.0 ( 1 to 3 ), $3.0 \pm 1.1$ (l to 6); basophils, 0.5 (0 to 1 ), 0.3 (0 to 1 ), -; monocytes, 3.5 (3 to 4), 2.3 (2 to 5 ), $1.8 \pm 0.5$ ( 1 to 3 ); hemoglobin concentration (g/ $100 \mathrm{ml}$ ) was 18.3 (18.2 to 18.4$), 17.6$ (16.8 to 18.6$), 15.5$ (15.3 to 15.7 ). These authors also gave the diameter in microns (mean \pm $1 \mathrm{SE}$, range) of erythrocytes of nine adult $B$. cavernarum (sexes combined) and eight pregnant females as follows: $5.5 \pm 0.4$ (4.1 to 7.7$)$, and $5.5 \pm 0.06$ (4.1 to 7.6).

Valdivieso and Tamsitt (1974) presented data on the serum proteins of a single lactating female from Puerto Rico. This individual had a total serum protein of $6.03 \mathrm{~g} / 100 \mathrm{ml}$. Of the bats tested, this individual had the greatest percentage of protein in the gamma region. The overall serum pattern of $B$. cavernarum was found to be unlike that of Erophylla and to be more similar to that of the vespertilionid bat Eptesicus fuscus.

McDaniel (1976) studied both the external and internal morphology of the brain of Brachyphylla cavernarum. Externally it was characterized by having relatively smooth and massive cerebral hemispheres. "The major cerebral sulci are well developed, including the sulcus anterior to the pseudocentral sulcus. The pseudotemporal lobes are ventrally angular, but do not protrude ventrally. The inferior colliculi are not visible from above. The vermiform body of the cerebellum is laterally enlarged and constitutes half of the dorsal exposure of the cerebellar tissues." An additional external character of the brain of Brachyphylla cavernarum, not found in any other phyllostomid brain, was the greatly enlarged uvular portion of the cerebellum which formed a prominent lobe at the posterior edge of the vermiform body along the dorsal surface of the medulla.

The internal structure of the brain of $B$. cavernarum differs in some ways from that of other phyllostomids (McDaniel, 1976). The cerebrum is remarkably circular in cross section. "Anteriorly, the interhemispheric sulcus includes only a well-developed cingulate sulcus. Posteriorly, there is a shallow cingulate sulcus and a callosal sulcus similar to that of the Desmodontinae. Cortical cells dorsal to the corpus callosum and substantia alba do not form a dense layer distinct from the overlaying cortex." Of all the brains of phyllostomid species studied, that of $B$. cavernarum is the only one in which the lateral olfactory tracts are located on the lateral aspects of the cerebrum. "The lateral thalamic nuclei project no higher than the habenular nuclei. The amygdaloid nuclei are large as in the phyllostomatines. The pons is deep, wide, and ventrally flattened."

According to McDaniel (1976) the magnitude and nature of the differences between the structure of the brains of $B$. cavernarum and Erophylla bombifrons indicate a greater divergence than within any other subfamily of phyllostomids. He did not examine the brain of Phyllonycteris. On the basis of brain anatomy, McDaniel (1976) concluded that the affinities of Brachyphylla cavernarum are with the Desmodontinae or possibly the Stenoderminae rather than with the other brachyphyllines.

The structure of the alimentary tract of $B$. cavernarum was reported on by Rouk (1973) and Forman et al. (1979). The esophagus enters the stomach near the gastroduodenal junction with the result that the lesser curvature between the esophagus and duodenum is extremely short. The fundic caecum is well developed, forming a bag-like structure that appears to be nearly compartmentalized into a two-chambered structure. The caecum bends abruptly anteriorly about midway along its length. Here there is a constriction in the muscularis externa which has not been found to function as a sphincter. The duodenum is enlarged where it enters the stomach, which is separated from the intestine by a distinctive construction. The stomach of Brachyphylla is distinctive among the phyllostomids; however, no other brachyphylline stomach has been studied.

The valve flap of the pyloric sphincter of bats that feed on plant material, including fruit, nectar, and pollen, is nearly always longer and thinner than valves of bats that feed on animal material. This feature is particularly well developed in B. cavernarum, and in the stenodermines (Forman et al., 1979). B. cavernarum is among the species of phyllostomids with the longest intestines relative to body length (Forman et al., 1979).

The mucus-producing glands of Brunner are generally restricted to an extremely narrow submucosal ring at the gastroduodenal junction of the stomach. Several unusual conditions with respect to Brunner's glands occur within the phyllostomids. In B. cavernarum, the only brachyphylline examined by Forman et al. (1979), these glands were absent.

Forman and Genoways (1979) found the head of the sperm of $B$. cavernarum to be of moderate length, and narrow. The symmetrically-shaped acrosome is considerably shorter than the nucleus, and has its posterior limit well anterior to the midpoint of the nucleus. The nucleus is more ovoid than that of Ardops, Ariteus, and Artibeus. The base of the head is slightly concave. The neck is short and the junction with the head is near the center. The midpiece is of moderate width, long, and tapers posteriorly; the junction with the tail is distinctive. Measurements (in microns) of sperm of two specimens from Guadeloupe are as follows: head length, $4.60,5.12$; acrosome length, 2.79, 2.79; nuclear length, 3.26, 3.53 ; width of head, $2.79,1.98$. The sperm of $B$. cavernarum was found to be unlike that of other brachyphyllines examined (for example, it differs in shape and size of the acrosome, relative length of midpiece, and symmetry of the head), and based on sperm morphology, B. cavernarum could be distinguished by its long midpiece.

ONTOGENY AND REPRODUCTION. Anthony (1918) reported that nursing females were collected on 5 July on Puerto Rico but no young were noted. During December 1956, Bond and Seaman (1958) examined 25 females from St. Croix, none of which showed enlarged uteri and ovarian follicles, nor grossly apparent corpora lutea. In males the testes measured from 4 to $6 \mathrm{~mm}$ long. All specimens examined were adult or subadult. Walker et al. (1964) reported lactating females from Puerto Rico in July, and Walker et al. (1975) reported pregnant females from there in February, and a lactating one in April, and on St. Croix pregnant females were observed in March. Nellis (1971) reported a lactating female from St. Croix during April.

Nellis and Ehle (1977) observed parturition to occur within a 3-week period during late May and early June on St. Croix. During this time the colony was almost exclusively composed of mothers and their single young together with only a few adult males or barren females. These authors also concluded that because simultaneous apparent population declines just prior to parturition occur throughout St. Croix, females may become solitary during this time.

Baker et al. (1978) captured 15 adult females on Guadeloupe during July of which none was pregnant, three were lactating, and four were postlactating. These authors surmised that B. cavernarum probably has a more synchronized reproductive cycle than, for instance, Artibeus. In 10 males captured during the same time the testes length was $4 \mathrm{~mm}$ for one individual, 5 for five, and 6 for four.

Of nine B. cavernarum taken from Montserrat, Jones and Baker (1979) reported six to have been adult females, four of which were lactating. Two adult males had testes measuring 6 and $7 \mathrm{~mm}$ in length. One individual was a volant young.

Based upon the available data, Wilson (1979) suggested a synchronized reproductive cycle in $B$. cavernarum. He also sug. gested that a second period of parturition occurred annually in at least some populations.

ECOLOGY. Bats of the species Brachyphylla cavernarum have been reported to roost in the following situations: in small colonies in old disused buildings or in dense tree tops on St. Croix (Beatty, 1944); in large numbers in suitably sized caves, frequently in well-lighted areas near the entrance, even in extensive caves on Puerto Rico (Anthony, 1918, 1925); in caves and in an under ground unused sugar house on St. Croix, always in complete darkness (Koopman, 1975); in a deep crevice on St. Croix (Valdivieso and Tamsitt, 1971). On St. Croix, Nellis and Ehle (1977) found that they generally roosted in large colonies in dark sites; however, a colony of 5,000 bats illuminated by direct sunlight was found in a large well ( $4 \mathrm{~m}$ in diameter and $50 \mathrm{~m}$ deep), another colony was in a sea cliff cleft with subdued lighting, and another small colony was hanging from the wooden beam ceiling of a dimly lighted ware- 
house. In captivity Nellis and Ehle (1977) found B. cavernarum selecting the darkest area of the cage to roost. They concluded that the use of lighter roosts is atypical and ascribed this behavior to a lack of more suitable locations in an otherwise favorable environment. On St. Croix, roosts were found to be monospecific.

The microclimate in Coles Cave on Barbados inhabited by $B$. cavernarum was described by Schwartz (in Buden, 1977) as being "moist and humid but not extremely hot" as were caves inhabited by $B$. nana on Cuba. Individuals of $B$. cavernarum have been taken on St. Eustatius on a steep-sided volcanic crater in a net placed across a path at the rim of the crater. Other bats taken in this net were of the species Ardops nichollsi and Artibeus jamaicensis (Ray, pers. comm., in Jones and Schwartz, 1967). On Dominica B. cavernarum was netted together with Ardops, Artibeus, Monophyllus, and Sturnira over a rock-strewn gravel bar in the Layou River (Jones and Schwartz, 1967; Schwartz and Jones, 1967). Homan and Jones (1975) also reported Myotis dominicensis being taken with $B$. cavernarum on Dominica.

B. cavernarum occurs in "dry arborescent vegetation" on St. John together with Stenoderma rufum, Noctilio leporinus, Artibeus jamaicensis, Tadarida brasiliensis, and Molossus molossus (Hall and Bee, 1960). In the Laquillo National Forest on Puerto Rico, bats of the species $B$. cavernarum were netted above the forest canopy together with those of $S$. rufum and A. jamaicensis. However, B. cavernarum was not found under the canopy of the broad-leafed forest at this place (Jones et al., 1971). Anthony (1918) noted that $A$. jamaicensis and $B$. cavernarum are often associated and are very similar in habits.

Although $B$. cavernarum occurred at six of the nine collecting localities sampled on Guadeloupe, it was common only at one on Grande-Terre in a dry canyon containing low dry scrub where netting took place under native trees. The limestone nature of GrandeTerre, which may provide caves and rock crevices for roosting, might be the reason that these bats are more common there (Baker et al., 1978). Elsewhere on Guadeloupe, these bats were taken over a boulder-strewn river in rain forest over a large stream lined with gallery forest, and high on the southwest slopes of the Sufriere volcano where banana groves gave way to tall native forest. Other bats taken at these same locations include those of the species $A$. jamaicensis, Ardops nichollsi, and M. molossus (Genoways and Jones, 1975).

Six wheelbarrow loads of dead $B$. cavernarum were removed after about 2,000 bats were gassed in an old sugar house on St. Croix during December 1956. The bats consisted of both adult and subadult animals. One load yielded a sex ratio of 63 males to 276 females (Bond and Seaman, 1958).

The diet of B. cavernarum is pollen, fruit, and insects (Bond and Seaman, 1958; Gardner, 1977; Nellis, 1971; Nellis and Ehle, 1977). Nellis (1971) found this bat on St. Croix eating the fruit of Manilkara zapota, and Nellis and Ehle (1977) found it feeding on papaya (Carica papaya), mango (Mangifera indica), West Indian almond (Terminalia catappa), manjack (Cordia spp.), royal palm (Roystonea boringuena), and sapodilla (Manilkara zapota). The latter authors also found captive bats to feed on bananas, apples, pears, melons, peaches, but not citrus, and the flowers of silk cotton (Ceiba pentandra), sausage tree, royal palm, portia tree (Thespesia populnea), and locust (Hymenaea courbaril).

Nellis and Ehle (1977) were unable during their field observations to distinguish between pollen and nectar consumption. Droppings from roosts mainly showed pollen. They found stomach contents from specimens collected while feeding on locust flowers to contain pollen and fluid that might have been nectar. Coprophagy was observed when sticky feces adhered to the fur and were removed by grooming.

Although individuals of $B$. cavernarum were netted while carrying ripe sapodilla fruit (Manilkara zapota), these were never carried to the roosts (Nellis, 1971). Bats were found to feed in the upper parts of the tree canopy. However, they were also observed feeding on the ground on fallen fruit or flowers (Nellis and Ehle, 1977).

One species of mite (Macronyssidae), two species of batfly (Streblidae), one species of tick (Argasidae), and two species of labidocarpid are known from B. cavernarum as follows (Cruz et al., 1974; Tamsitt and Fox, 1970a, 1970b; Webb and Loomis, 1977): Redfordiella oudemansi (Puerto Rico), Nycterophilia coxata (British West Indies), Trichobius truncatus (Puerto Rico), Ornithodoros hasei (Guadeloupe, Martinique), Lawrenceocarpus micropilus (Puerto Rico), and L. puertoricensis (Puerto Rico). In addition Bond and Seaman (1958) observed fleas and batflies (Streblidae) on these bats from St. Croix. Valdivieso and Tamsitt (1971) observed no hemoparasites in specimens from St. Croix. No endo- parasites have been recorded from $B$. cavernarum (Ubelaker et al., 1977).

BEHAVIOR. Brachyphylla cavernarum was described as being quarrelsome and petulant by Anthony (1918), and belligerent and pugnacious both towards conspecifics and other species by Nellis and Ehle (1977). The latter authors observed fighting to be so severe at times that broken wings resulted. In spite of this Nellis and Ehle (1977) and Fenton and Kunz (1977) found them in tight groups during the day with individual bats frequently moving from one group to another. In a large roost the general appearance was that the bats were active most of the day, grooming, quarreling, or moving around. Individuals or groups appear to sleep only for short intervals.

Initial emergence from roosts was found to be synchronous at more than an hour after sunset and at least 20 minutes after the emergence of $A$. jamaicensis from similar roosts. A similar synchrony with a sharp drop in activity just before the first evidence of dawn was found for the returning bats.

The following observations on the feeding behavior of B. cav . ernarum were reported by Nellis and Ehle (1977). When feeding on flowers they mouth the anthers and extend their tongues into the nectaries. On juicy fruit, they rapidly lick, stopping every few seconds to swallow. Firm fruit is chewed until the pulp is dry, after which it is discarded by shaking the head with the mouth open. In captivity, the bats treat flies and mealworms in a similar manner.

Individuals of Brachyphylla cavernarum usually tolerated conspecifics feeding on the same or nearby fruit or flowers, but hostility was shown towards any $A$. jamaicensis in the vicinity. When $B$. cavernarum began feeding in the upper parts of the canopy, A. jamaicensis moved to the lower areas. As B. caver narum started feeding lower, $A$. jamaicensis gave way completely. $A$. jamaicensis never succeeded in displacing $B$. cavernarum at a feeding site (Nellis and Ehle, 1977). An individual of B. cavernarum often landed on or near a feeding A. jamaicensis and would then chase it. $B$. cavernarum was found to be much better at clambering about on trees than $A$. jamaicensis, usually climbing to nearby flowers, whereas A. jamaicensis flew there (Nellis and Ehle, 1977).

In a captive colony, immatures became active first. Self. grooming was the first activity on arousal. Mutual grooming was observed infrequently between adults but more commonly between mother and young (Nellis and Ehle, 1977).

Recognition of roostmates or parent-child recognition is based primarily on smell. The first few weeks of life, the young mostly groom, sleep, and nurse. First free flight occurs at about 2 months of age. During a year of severe drought, mortality of both mother and young was found to be very high. Some roosts were abandoned and it was surmised that this might have been because of the stench of dead and rotting bats (Nellis and Ehle, 1977).

GENETICS. Brachyphylla cavernarum has a diploid chromosomal number of 32 ; there are 60 autosomal arms. All the autosomes are metacentric or submetacentric. The $\mathrm{X}$ chromosome is subtelocentric and the $\mathrm{Y}$ is a minute element. There is a secondary constriction on one of the smallest pairs of autosomes (Baker and Lopez, 1970).

Baker et al. (1981) suggested that a karyotype similar to that of B. cavernarum and characteristic of Glossophaga was primitive for a clade including the Brachyphyllinae and the glossophagine genera Anoura, Glossophaga, Monophyllus, Leptonycteris, Hylonycteris, and Choeroniscus.

REMARKS. The genus Brachyphylla was erected by Gray in 1834. Gray (1838) placed the genus in the tribe Phyllostomina of the family Vespertilionidae. Gervais $(1855-1856)$ placed the genus in the tribe Stenodermina, which subsequently was recognized as the subfamily Stenoderminae of the family Phyllostomidae. In 1866, Gray erected the tribe Brachyphyllina with Brachyphylla as the sole genus. Later, Dobson (1878) included Brachyphylla in his group Stenodermata but stated that it was the most closely related of all known genera of phyllostomids to the desmodontines. In fact, Winge (1892) arranged it as a desmodontine, and McDaniel (1976), in his study of the brain anatomy, also thought the Brachy. phylla was most closely allied to the desmondontines, or possibly the stenodermines. Allen (1898) placed Brachyphylla in the subfamily Glossophaginae, but separated it in a group termed Brachy. phyllina along with Phyllonycteris and Erophylla. Miller (1898), in describing Reithronycteris (=Phyllonycteris), followed this arrangement but clearly allied Reithronycteris with Brachyphylla, Phyllonycteris, and Erophylla. Miller later changed his opinion and stated that he could detect no indication that Brachyphylla was a phyllonycterine and placed it in the subfamily Stenoderminae 
(Miller, 1907). Here it remained until Silva-Taboada and Pine (1969) presented evidence based on osteology, behavioral characteristics, and host-parasite specificity for considering Brachyphylla a member of the subfamily Phyllonycterinae. However, as Baker (1979) pointed out, Brachyphyllinae is the oldest available family-group name for the subfamily. Slaughter (1970) reflected on the similarity between this genus and Sturnira and thought it possible that these two genera, in addition to the glossophagines and stenodermines, were related to some unknown common ancestor, and concluded that the dentition offered no evidence that Brachyphylla was any more closely related to the stenodermines than Sturnira. The latter is now included in the Stenoderminae by most authorities. Analysis of the chromosomes of Glossophaga soricina, Monophyllus redmani (Glossophaginae), Phyllonycteris aphylla, Erophylla sezekorni, and Brachyphylla nana (Brachyphyllinae), indicated no detectable differences in the G. and C-band patterns among the karyotypes of these species (Baker and Bass, 1979). These taxa have been found not to be closely allied to the Stenoderminae on the basis of chromosomal data (Baker et al., 1979). Baker and Bass (1979) surmised that if the primitive karyotype for the family Phyllostomidae is similar to that of Macrotus waterhousii, then the above members of the Glossophaginae and Brachyphyllinae shared a common ancestor after evolving their highly derived karyotypes. This evidence casts doubt on the validity of the subfamily Brachyphyllinae, which perhaps should be placed in the Glossophaginae. However, Baker et al. (1981) found that both electrophoretic and immunological data sets supported the hypothesis that the Brachy. phyllinae forms a natural evolutionary unit.

In erecting the genus Brachyphylla, Gray (1834) described cavernarum from St. Vincent as the first species. Subsequently three additional species were described, nana by Miller (1902) from Cuba, minor by Miller (1913) from Barbados, and pumila by Miller (1918) from Haiti. Koopman (1968) presented evidence for considering minor a subspecies of cavernarum. Varona (1974; see also Hall, 1981), without presenting any evidence, recognized only one species, $B$. cavernarum, with all other previously recognized species as subspecies thereof. Jones and Carter (1976) and Silva-Taboada $(1976,1979)$ recognized two species, B. cavernarum and B. nana, with minor as a subspecies of the former and pumila of the latter. Buden (1977), studying geographic variation in Greater Antillean populations, agreed with Varona's (1974) arrangement. Swanepoel and Genoways (1978), in a revision of the genus, showed it to consist of two species, B. cavernarum and B. nana. The former species consists of three subspecies, one of which was described as new, and the latter is a monotypic species.

Zoogeographically, the genus Brachyphylla is an endemic to the Antillean islands. It is a member of the otherwise Greater Antillean subfamily Brachyphyllinae. The probability that $B$. cavernarum originated in the Greater Antilles and subsequently invaded the Lesser Antilles is greater than the reverse (Baker and Genoways, 1978; Koopman, 1975).

The generic name, formed from the Greek words brachys and phyllon, means "short leaf" in reference to the short, broad noseleaf of members of the genus. The specific name is from Latin and refers to caves or grottos in which this species typically roosts. The subspecific epithets intermedia and minor refer to the general overall size, intermediate and small, respectively, of the individuals of the two subspecies.

\section{LITERATURE CITED}

Allen, H. 1898. On the Glossophaginae. Trans. Amer. Phil. Soc., 19:237-266

Anthony, H. E. 1918. The indigenous land mammals of Porto Rico, living and extinct. Mem. Amer. Mus. Nat. Hist., new ser., 2(2):33l-435.

1925. Mammals of Porto Rico, living and extinct-Chiroptera and Insectivora. New York Acad. Sci. Scientific Survey of Porto Rico and Virgin Islands, 9:1-96.

Baker, R. J. 1979. Karyology. Pp. 107-155, in Biology of bats of the New World family Phyllostomatidae, Part 3 (R. J. Baker, J. K. Jones, Jr., and D. C. Carter, eds.). Spec. Publ. Mus., Texas Tech Univ., 16:1-441.

Baker, R. J., and R. A. Bass. 1979. Evolutionary relationship of the Brachyphyllinae to the glossophagine genera Glos sophaga and Monophyllus. J. Mamm., 60:364-372.

Baker, R. J., and H. H. Genoways. 1978. Zoogeography of Antillean bats. Spec. Publ. Acad. Nat. Sci. Philadelphia, 13: $53-97$.

Baker, R. J., and G. Lopez. 1970. Karyotypic studies of the insular populations of bats on Puerto Rico. Caryologia, 23: $465-472$.
Baker, R. J., R. A. Bass, and M. A. Johnson. 1979. Evolutionary implications of chromosomal homology in four genera of stenodermine bats (Phyllostomatidae: Chiroptera). Evolution, 33: $220-226$.

Baker, R. J., H. H. Genoways, and J. C. Patton. 1978. Bats of Guadeloupe. Occas. Papers Mus., Texas Tech Univ., 50:116 .

Baker, R. J., et al. 1981. Electrophoretic and immunological studies on the relationship of the Brachyphyllinae and Glossophaginae. J. Mamm., 62:665-672.

Beatty, H. A. 1944. Fauna of St. Croix, V. I. J. Agric., Univ. Puerto Rico, 28:181-185.

Benedict, F. A. 1957. Hair structure as a generic character in bats. Univ. California Publ. Zool., 59:285-548.

Bond, R. M., and G. A. Seaman. 1958. Notes on a colony of Brachyphylla cavernarum. J. Mamm., 39:150-15l.

Buden, D. W. 1977. First records of bats of the genus Brachyphylla from the Caicos Islands, with notes on geographic variation. J. Mamm., 58:221-225.

Choate, J. R., and E. C. Birney. 1968. Sub-Recent Insectivora and Chiroptera from Puerto Rico, with the description of a new bat of the genus Stenoderma. J. Mamm., 49:400-412.

Cruz, J. de la, J. R. Tamsitt, and D. Valdivieso. 1974. Three new species of labidocarpine mites (Listrophoroidea, Chirodiscidae) from Puerto Rican bats. Life Sci. Occas. Papers, Royal Ontario Mus., 23:1-13.

Dobson, G. E. 1878. Catalogue of the Chiroptera in the collection of the British Museum. British Museum (Nat. Hist.), London, $567 \mathrm{pp}$.

Fenton, M. B., and T. H. Kunz. 1977. Movements and behavior. Pp. 351-364, in Biology of bats of the New World family Phyllostomatidae, Part 2 (R. J. Baker, J. K. Jones, Jr., and D. C. Carter, eds.). Spec. Publ. Mus., Texas Tech Univ., 13: l-44l.

Forman, G. L., and H. H. Genoways. 1979. Sperm morphology. Pp. 177-204, in Biology of bats of the New World family Phyllostomidae, Part 3 (R. J. Baker, J. K. Jones, Jr., and D. C. Carter, eds.). Spec. Publ. Mus., Texas Tech Univ., 16:1441 .

Forman, G. L., C. J. Phillips, and C. S. Rouk. 1979. Alimentary tract. Pp. 205-227, in Biology of bats of the New World family Phyllostomatidae, Part 3 (R. J. Baker, J. K. Jones, Jr., and D. C. Carter, eds.). Spec. Publ. Mus., Texas Tech Univ., $16: 1-441$.

Gardner, A. L. 1977. Feeding habits. Pp. 293-350, in Biology of bats of the New World family Phyllostomatidae, Part 2 (R. J. Baker, J. K. Jones, Jr., and D. C. Carter, eds.). Spec. Publ. Mus., Texas Tech Univ., 13:1-364.

Genoways, H. H., and J. K. Jones, Jr. 1975. Additional records of the stenodermine bat, Sturnira thomasi, from the Lesser Antillean island of Guadeloupe. J. Mamm., 56:924-925.

Gervais, P. 1855-1856. Documents zoologiques pour servir à la monographie des chéiroptères sud-americains. In Mammiféres. Animaux nouveaux ou rares recueillis pendant l'expédition dans les parties centrales de l'Amerique du Sud (F. de Castelnau, ed.). Paris Part 7 (Zoologie). Vol. for 1855:25-88.

Gray, J. E. 1834. Characters of a new genus of bats (Brachy. phylla), obtained by the Society from the collection of the late Rev. Lansdown Guilding. Proc. Zool. Soc. London, pp. 122123.

1838. A revision of the genera of bats (Vespertilionidae), and the description of some new genera and species. Mag. Zool. Bot., 2(12):483-505.

- 1866. Revision of the genera of Phyllostomidae, or leafnosed bats. Proc. Zool. Soc. London, pp. 111-118.

Hall, E. R. 1981. The mammals of North America. Second ed. John Wiley and Sons, New York, 1:1-600 + 90 .

Hall, E. R., and J. W. Bee. 1960 . The red fig-eating bat Stenoderma rufum Desmarest found alive in the West Indies. Mam. malia, 24:67-75.

Homan, J. A., and J. K. Jones, Jr. 1975. Monophyllus plethodon. Mammalian Species, 58:1-2.

Jones, J. K., Jr., and R. J. Baker. 1979. Notes on a collection of bats from Monserrat, Lesser Antilles. Occas. Papers Mus., Texas Tech Univ., 60:1-6.

Jones, J. K., Jr., and D. C. Carter. 1976. Annotated checklist, with keys to subfamilies and genera. Pp. 7-38, in Biology of bats of the New World family Phyllostomatidae, Part l (R. J. Baker, J. K. Jones, Jr., and D. C. Carter, eds.). Spec. Publ. Mus., Texas Tech Univ., 10:1-218.

Jones, J. K., Jr., and A. Schwartz. 1967. Bredin-Archbold-Smithsonian Biological Survey of Dominica. 6. Synopsis of bats of 
the Antillean genus Ardops. Proc. U.S. Natl. Mus., 124(3634): $1-13$.

Jones, J. K., Jr., H. H. Genoways, and R. J. Baker. 1971. Morphological variation in Stenoderma rufum. J. Mamm., 52: $244-247$.

Klite, P. D. 1965. Intestinal bacterial flora and transit time of three Neotropical bat species. J. Bacteriol., 90:375-379.

Koopman, K. F. 1968. Taxonomic and distributional notes on Lesser Antillean bats. Amer. Mus. Novitates, 2333:1-13.

- 1975. Bats of the Virgin Islands in relation to those of the Greater and Lesser Antilles. Amer. Mus. Novitates, 2581: $1-7$.

McDaniel, V. R. 1976. Brain anatomy. Pp. 147-200, in Biology of bats of the New World family Phyllostomatidae, Part l (R. J. Baker, J. K. Jones, Jr., and D. C. Carter, eds.). Spec. Publ. Mus., Texas Tech Univ., 10:1-218.

McManus, J. J. 1977. Thermoregulation. Pp. 281-292, in Biology of bats of the New World family Phyllostomatidae, Part 2 (R. J. Baker, J. K. Jones, Jr., and D. C. Carter, eds.). Spec. Publ. Mus., Texas Tech Univ., 13:1-364.

McManus, J. J., and D. W. Nellis. 1972. Temperature regulation in three species of tropical bats. J. Mamm., 53:226-227.

Miller, G. S., Jr. 1898. Descriptions of five new phyllostome bats. Proc. Acad. Nat. Sci. Philadelphia, 50:326-337.

- 1902. Twenty new American bats. Proc. Acad. Nat. Sci. Philadelphia, 54:389-412.

- 1907. The families and genera of bats. Bull. U.S. Natl. Mus., $57: 1-282$.

- 1913. Five new mammals from tropical America. Proc. Biol. Soc. Washington, 26:31-34.

- 1918. Three new bats from Haiti and Santo Domingo. Proc. Biol. Soc. Washington, 31:39-40.

Nellis, D. W. 1971. Additions to the natural history of Brachy. phylla (Chiroptera). Caribbean J. Sci., 11:91.

Nellis, D. W., and C. P. Ehle. 1977. Observations on the behavior of Brachyphylla cavernarum (Chiroptera) in Virgin Islands. Mammalia, 41:403-409.

Reynolds, T. E., K. F. Koopman, and E. E. Williams. 1953. A cave faunule from western Puerto Rico with a discussion of the genus Isolobodon. Breviora, 12:1-8.

Rouk, C. S. 1973. Gastric morphology and adaptive radiation in the Phyllostomatidae. Unpubl. Ph.D. dissert., Texas Tech Univ., $85 \mathrm{pp}$.

Schwartz, A., and J. K. Jones, Jr. 1967. Bredin-Archbold-Smithsonian Biological Survey of Dominica. 7. Review of bats of the endemic Antillean genus Monophyllus. Proc. U.S. Natl. Mus., 124(3635): 1-20.

Silva-Taboada, G. 1976. Historia y actualización taxonómica de algunas especies Antillanas de murciélagos de los géneros Pteronotus, Brachyphylla, Lasarius, y Antrozous (Mammalia: Chiroptera). Poeyana, 153:1-24.

- 1979. Los murciélagos de Cuba. Editorial Academia, Acad. Cien. Cuba, Habana, 423 pp.

Silva-Taboada, G., and R. H. Pine. 1969. Morphological and behavioral evidence for the relationship between the bat genus Brachyphylla and the Phyllonycterinae. Biotropica, 1:1019.

Slaughter, B. H. 1970. Evolutionary trends of chiropteran dentitions. Pp. 51-83, in About bats (B. H. Slaughter and D. W.
Walton, eds.). Southern Methodist Univ. Press, Dallas, Texas, $339 \mathrm{pp}$.

Smith, J. D. 1976. Chiropteran evolution. Pp. 49-69, in Biology of bats of the New World family Phyllostomatidae, Part l (R. J. Baker, J. K. Jones, Jr., and D. C. Carter, eds.). Spec. Publ. Mus., Texas Tech Univ., 10:1-218.

Smith, J. D., and A. Starrett. 1979. Morphometric analysis of chiropteran wings. Pp. 229-316, in Biology of bats of the New World family Phyllostomatidae, Part 3 (R. J. Baker, J. K. Jones, Jr., and D. C. Carter, eds.). Spec. Publ. Mus., Texas Tech Univ., 16:1-441.

Swanepoel, P., and H. H. Genoways. 1978. Revision of the Antillean bats of the genus Brachyphylla (Mammalia: Phyllostomatidae). Bull. Carnegie Mus. Nat. Hist., 12:1-53.

Tamsitt, J. R., and I. Fox. 1970a. Mites of the family Listrophoridae in Puerto Rico. Canadian J. Zool., 48:398-399.

- 1970b. Records of bat ectoparasites from the Caribbean region (Siphonaptera, Acarina, Diptera). Canadian J. Zool., 48:1093-1097.

Ubelaker, J. E., R. D. Specian, and D. W. Duszynski. 1977. Endoparasites. Pp. 7-56, in Biology of bats of the New World family Phyllostomatidae, Part 2 (R. J. Baker, J. K. Jones, Jr., and D. C. Carter, eds.). Spec. Publ. Mus., Texas Tech Univ., $13: 1-364$

Valdivieso, D., and J. R. Tamsitt. 1971. Hematological data from tropical American bats. Canadian J. Zool., 49:31-36.

- 1974. Electrophoretic patterns of serum proteins of Neotropical bats (Chiroptera). Life Sci. Contrib., Royal Ontario Mus., 98:1-24.

Varona, L. S. 1974. Catálogo de los mamíferos vivientes y extinguidos de las Antillas. Acad. Cien. Cuba, Habana, 139 pp.

Walker, E. P., et al. 1964. Mammals of the world. Johns Hopkins Univ. Press, Baltimore, 1:1-644.

- 1975. Mammals of the world. Third ed. Johns Hopkins Univ. Press, Baltimore, l:1-644.

Webb, J. P., Jr., and R. B. Loomis. 1977. Ectoparasites. Pp. $57-119$, in Biology of bats of the New World family Phyllostomatidae, Part 2 (R. J. Baker, J. K. Jones, Jr., and D. C. Carter, eds.). Spec. Publ. Mus., Texas Tech Univ., 13:1-364.

Wilson, D. E. 1979. Reproductive patterns. Pp. 317-378, in Biology of bats of the New World family Phyllostomatidae, Part 3 (R. J. Baker, J. K. Jones, Jr., and D. C. Carter, eds.). Spec. Publ. Mus., Texas Tech Univ., 16:1-44l.

Wing, E. S., C. A. Hoffman, Jr., and C. E. Ray. 1968. Vertebrate remains from Indian sites on Antigua, West Indies. Caribbean J. Sci., 8:123-139.

Winge, H. 1892. Jordfundne ogl nulevende Flagermus (Chiroptera) fra Lagoa Santa, Minas Geraes, Brasilien, mach Udsigt ove Flagermusenes indtyndes Scaetkab. E Museo Lundii, 2: $1-65$.

Editors of this account were Daniel F. WILliams and SydNEY ANDERSON. Managing editor was TIMOTHY E. LAwlor.

P. Swanepoel, Kaffrarian Museum, King William's Town, 5600, Republic of South Africa, and H. H. Genoways, Carnegie Museum of Natural History, 4400 Forbes Ave., Pittsburgh, PenNSylvania 15213. 